\title{
Improving Students' Oral Communication Skills in Public Speaking through Individual Presentation Task
}

\begin{abstract}
Ahmad Burhanuddin
Fakultas Tarbiyah dan Ilmu Keguruan, IAIN Pekalongan, Indonesia

ahmad.burhanuddin@iainpekalongan.ac.id

DOI: 10.20884/1.jli.2021.12.2.4002

Article History:

First Received:

ABSTRACT

$03 / 03 / 2021$

This current study attempts to seek the answers of a question: how

Final Revision: effective is the individual presentation method in improving students'

$06 / 12 / 2021$ oral communication skills, especially in public speaking? Designed as

Available online: a qualitative research, this research was conducted at the Faculty of Tarbiyah and Teacher Training of IAIN Pekalongan in the academic

$31 / 12 / 2021$ year of 2019/2020. The research involved 100 of the second year students of the English Education Department of IAIN Pekalongan who took Public Speaking course. The data were collected through an open-ended questionnaire as the instruments of this study to get their perception after taking the course with performing an individual presentation as its main task. The research findings reveal despite the obstacles they encountered, the presentation task was effective to enhance students' confidence as well as to give them experience to speak in front of a crowd. The task also gave them more awareness and self-evaluation on how to perform a good public speaking as they received direct feedback from the audience while performing the individual presentation.
\end{abstract}

Keywords: oral communication skills; public speaking; presentation

\section{INTRODUCTION}

Communicative competence can be defined as an individual ability to use language effectively in actual communication (Hymes in Goh, C., M., \& Burns, 2012). However, in the classroom practice there is a tendency not to balance the four strands; in fact, some skills are neglected such as oral communication skills. A well balanced language course should consist of four equal strands which is meaning focused input, meaning-focused output, language-focused learning, and fluency development (Nation, 2012).

Communication is the exchange of ideas between people both verbally and in writing where there is an exchange of meaning and information. A communication "involves not only words, but also symbols and spoken word gestures because symbolic actions are not limited to 
communicative utterances" (Rahman, 2010). In oral communication, speaking occurs in front of the listener because the listener responds to the speaker's communication. Byrne defines, "oral communication is a two-way process between speaker and listener and involves productive speaking skills and receptive comprehension skills" (Byrne, 1986)He further defines "an interactive process" in which two communications, namely sender and receiver, are involved in the process. Effective OC cannot simply be 'learned' by reading. It needs to be planned, strategized, practiced and assessed, preferably in an 'authentic' setting (Chan, 2011).

As the students in the Faculty of Education and Teachers Training are prepared to be teachers, communicative skill, especially speaking in public, is a must have skill for them. However, over the years, teaching speaking has become obsolete and English teachers have continued to teach speaking only as a repetition of the practice or memorization of dialogue. Consequently, the number of students' who are able to communicate in English intelligibly is still limited although they have been studying English for years (Lie, 2007). Thus, appropriate method of teaching is one of pivotal factors to the success of the students in terms of building their language skill, especially speaking in public. Teachers can use different strategies of teaching to achieve teaching-learning goals and objectives (Reiser, R. A., \& Dick, 1996). It is the teacher's role to provide effective plans/strategies in accomplishing students' educational needs, whose general purpose is to communicate using the language being learnt (Cole, 2008). These imply that it is teachers' responsibility to make students speak English by employing suitable teaching strategies of speaking.

A various number of speaking teaching strategies are utilized and used in the classrooms for many circumstances. Among others, the strategies of teaching speaking are simulation, communication games, drilling and discussion. Simulations are activities where students are asked to pretend to be in various social contexts and various social roles (Thornbury, 2005). Discussion resemble real-life tasks as (Solcova, 2011) asserts that students develop their fluency best, if engaged in tasks where all their concentration focuses on producing something, rather than on the language itself. Drilling, as (Thornbury, 2005) argues, is a strategy to improve pronunciation by imitating and repeating words, phrases, and even whole utterances. It functions to make students pay attention to the new materials and emphasize words, phrases, or utterances on students' mind, move new items from working memory to long term memory, provide means of gaining articulatory control over language (Thornbury, 2005).

Another skill which is essential for teachers is public speaking skill. Thus, courses on public speaking typically cover topics such as listening, critical thinking, writing outlines, and effectively organizing ideas and information-all of which are critically important 
skills for college success (Morgan, 2008). In this public speaking course students are given a chance to practice in front of their classmates. The public speaking course is designed in such a way as to encourage students to overcome fear of speaking in public and to enjoy it at the same time (Al-Tamimi, 2014). Qutbi found that the students showed improvement after being given the opportunity to practice spoken language, provided learning environment and using new teaching strategies. Also found that over codes, self-error correction, the use of pauses and fillers cannot be avoided to improve speaking skills in the second language learning process (Qutbi, 2013). Oradee found that speaking ability after using discussion method, problem solving, and playing a much higher role than before the use of these methods (Oradee, 2012).Gudu recommended that students should be given the opportunity to practice using native English in context, the teacher must integrating various activities in the lesson to meet the needs of participants students and 3) curriculum for cultural backgrounds in order to improve their learning outcomes (Gudu, 2015).

The existing studies have examined various methods of teaching speaking skills or Oral Communication Skill (OCS); however, none of them discussed about how students felt about performing an individual presentation as one form of public speaking in relation with their speaking skill. This study aims to find out to what extent the level of effectiveness of this individual presentation method in improving students' oral communication skills (OCSs) in using English from the students' perspective. This study seeks to answer a question: How effective is the individual presentation method in improving students' oral communication skills, especially in public speaking?

\section{MATERIALS AND METHOD}

This study is a field research by using qualitative approach to produce descriptive data in the form of words written or oral words and observable behavior. This approach describes data through the form of words or sentences and separated according to existing theories, to obtain clear and detailed information.

The participants of this research were 100second year students aged 19-20 in a university in Central Java Indonesia. A survey research design was used in this study since its purpose was find out the perception and preferences of a large group of the students on the use of presentation task for English public speaking course. As it is explained by (Latief, 2011) a survey research is normally used to describe point of views, attitudes, preferences, and perceptions of large 
population of interest to the researcher. By implementing this type of research, a representative data of a large population can be collected, tabulated and analyzed.

The data for this research were ccollected through an online questionnaire which consisted of 8 items of questions which were categorized into two types of questions, they were: questions about pre-activity and post activity of the task. The items were constructed in English were in the form of open-ended questions to get more information from the participants. In responding to the questionnaire, the participants were anonymous and the author had checked that all participants had responded to the questionnaire well.

The technique of data analysis also consisted of three stages, namely data reduction, data display, and drawing conclusion or verification. Data reduction refers to the process of selecting, focusing, simplifying, abstracting and transforming the data that appear in written-up field notes or transcriptions. The second stage, data display is the second element or level in Miles and Huberman's model of qualitative data. Data display goes a step beyond data reduction to provide an organized, compressed assembly of information that permits conclusion drawing and action. The data displayed or presented. A display can be an extended piece of text or diagram; chart or matrix that provided a new way of arranging and thinking about the more textually embedded data. The last stage Conclusion drawing involves stepping back to consider what the analyzed data mean and to assess their implications for the questions at hand.

\section{RESULTS \&DISCUSSION}

The participants reported that despite the obstacles they encountered, the task of giving an individual presentation has given positive impacts to their oral communication skills as it has improved their confidence to speak in English.

\section{Improving Students' Confidence}

To increase the self-confidence, the students can try to speak in public because public speaking is about delivering material in public with many people as the audience. Public speaking is becoming very helpful in everyday life especially in speech communication. Many people especially students do not realize the advantages of public speaking. It offers their opportunity to increase the level of confidence in their speech, gives them an opportunity to engage in social conversations with more assurance, to approach others and to express themselves freely in any situation (Adnan \& Abidin, 2017). Nowak (2004) stated that public speaking means that the way one expresses or communicates his or her opinions to the general public (Pratama, 2019). 
Most of the participants reported that doing individual presentation in front of their classmates has improved their confidence. One of the participants said, "After participating in this Public Speaking class, I felt a change that had occurred when I spoke in public. Ifeel more confident and more relaxed in saying whatever I want to say." Another participant reported a similar tone "After taking this public speaking class, my confidence increased.

Performing a presentation in front of a crowd is a tough task as it requires high confidence. Self-confidence is an essential thing in creating good communication, especially in public speaking (Nadiah, 2019).Self-confidence is a positive attitude of the individual that enables himself to against the environment or situation he faces. Lauster stated that self-confidence is convincing in the ability and self-assessment of the task and it has a practical approach (Indrawati, 2018).

By having a good confidence, it will be easier for us to convey message to the audience. The students who have a good self-confidence will be able to overcome fears or negative thoughts, so that they will communicate more effectively, especially in the oral presentation in front of the class. The students who can communicate fluently and confidently as a good impact of the high self-confidence is that the students can increase their academic achievement in the speaking course because the students fulfill the criteria of the assessment on speaking skill (Salim, 2015).

It means that someone who is confident and capable of dealing with the word includes he belief that he or she can expect success or failure (Salim, 2015). Self-confidence is the feeling or worthy that one feels for himself/herself (Nadiah, 2019). Feltz stated that self-confidence as rather than a general feature, it is a belief of a person that they can successfully achieve an activity and individuals' trust to their judgment, ability, strength, and decisions (Indrawati, 2018).

\section{Giving Students' Real Experience}

Experience is the best teacher, and to get the first experience is so important. Everyone can become a better public speaker through study and practice (Miller, 2017). Thus, we are going to make our students better at public speaking, teachers must be able to apply the lessons of instruction and imitation by practicing their speeches.

One participant reported, "I think giving a presentation in front of my classmates can improve my public speaking skills because it's like a first step in developing the ability to speak in public." From this response it can be inferred that, basically, if they are offered an option to speak in front of public, most of them prefer not doing it. In fact, they will never know how it 
feels until they experience it. Thus, giving opportunities to students to perform a presentation in front of the class is a good start for their next public speaking experiences in the future. Thus, by giving this individual presentation student are learning by doing. The learning by doing approach is effective in stimulating the natural curiosity of learners. The students in this approach develop critical thinking skills as well as the creativity in expressing themselves well (Hackathorn, et.al, 2011).

This classroom performance for some students might be their first ever experience. After they perform their first presentation, the second presentation in the future might be easier-at least less scary than the first one, and they will be more ready. One of the participants reported, "So when I've done well at public speaking in front of classmates, next I'll be braver or perhaps even more challenging to do public speaking in front of a bigger community than classmates." Thus, by performing a presentation in front of their classmates the students have learned a very good lesson about how to speak in front a crowd.

\section{Making Students’ Better Public Speaker}

The public speaking course is a unique course as it requires the students to both know content and be able to perform a skill well. Students will learn important principles of public speaking, but simply knowing these principles is insufficient; they must also be able to apply them well (Miller, 2017). Most of public speaking is a pre-planned activity, one of which is giving presentation. By giving a presentation - with advance preparation, students learned how to open a presentation, carry on a discussion, answer questions, and also attract audience's attention. One of the participant said, "After I took public speaking class, I know I need steps and many things we can pay attention to, before speaking in front of public, so I never feel nervous or confused because I already know what to do and where to start." Another participant said, "I became aware of the techniques to do in public speaking, especially in attracting the attention of audiences." Besides, the students also realized how to use their body language properly and effectively while performing a presentation. One of the participant said, "It can improve my public speaking skill because I am taught to express my ideas. I can improve with gesture, ex. I can use gesture with moving my hands to describe something that I tell the audience. I can express my feeling with facial expression so the audiences can get meanings." By using a correct body language, a presentation will be a successful and powerful public speaking. Specifically, the skills training approach involves training participants how to communicate effectively through both verbal and non-verbal channels, how to conduct research, how to organize 
thoughts, how to outline ideas, and how to practice speeches (Allen, M., Hunter, J. E., \& Donohue, 1989).

By performing directly in front of their classmates, the students train to move their hand and head properly to support their performance. They can also identify which part of their boy that might move uncontrollably as it might weaken the performance. One of the participants said that, "The key to a successful presentation is a delightful delivery. Because no matter how good the material is, if the way it is delivered is not interesting, it will seem boring." Thus, in this case after performing their presentation s/he could recognize his/her performance, whether it is interesting or boring. The best public speakers not only speak smoothly, they also say important and interesting things (Miller, 2017). In this case, students who perform should look at their audience whether they are following their explanation or not. Thus, the students are expected to self-evaluate their performance for their better future performance.

\section{CONCLUSION}

Giving a real experience to students especially for productive language skill such as speaking is proven to be effective. This individual presentation task is seen effective as the best way to enhance students' confidence as well as to practice their mental readiness as well as to train their body language to talk in front a crowd. In this case, once they can handle their classmates, they have a bigger opportunity to perform well in the future to speak in front different or even bigger audience. To be specified, this kind of skill is pivotal and essential for those going to be teachers who have tasks to communicate their knowledge and values to their students.

This present study reveals that the students' needs more practice in order to improve their speaking skill. This individual presentation gives the students to do learning by doing in which they can also improve their critical thinking as well as self-evaluation from direct feedback they receive while performing the presentation. However, this research lacks of precise measurement of the students' fluency in performing the presentation as one of oral communication skill tasks. In the future, other researcher might conduct a further study to see how much the increasing level of the fluency (such as the speed and the number of words per minute) before and after students performing the individual presentation task. 


\section{ACKNOWLEDGEMENT}

I would like express my gratitude to the Indonesian Ministry of Religious Affairs which has given the financial support and made this research possible.

\section{REFERENCES}

Adnan, N. I., \& Abidin, M. J. Z. (2017). Using Public Speaking to Improve Malaysian Students ' Confidence Level In Speaking Skill : A Case Study. International Journal of Education, Islamic Studies and Social Sciences Research, 01(1).

Al-Tamimi, N. O. M. (2014). Public Speaking Instruction: Abridge to Improve English Speaking Competence and Reducing Communication Apprehension. International Journal of Linguistics and Communication, Vol. 2, No(December), 45-68.

Allen, M., Hunter, J. E., \& Donohue, W. A. (1989). Meta-analysis of self-report data on the effectiveness of public speaking anxiety treatment techniques. Communication Education, 38, $54-76$.

Byrne, D. (1986). Teaching Oral English. Longman.

Chan, V. (2011). Teaching oral communication in undergraduate science: Are we doing enough and doing it right? Journal of Learning Design, 4(3), 73.

Cole, R. W. (2008). Educating Everybody's Children: Diverse Teaching Strategies for Diverse Students, Revised and Expanded. Association for Supervision and Curriculum Development (ASCD).

Indrawati, E. (2018). Improving Self Confidence of Adolesense through Counseling Directive. International Journal of Science and Research (IJSR), 7, 373-375.

Goh, C. M., \& Burns, A. (2012). Teaching Speaking: A Holistic Approach. Cambridge University Press.

Gudu, B. O. (2015). Teaching Speaking Skills in English Language using Classroom Activities in Secondary School Level in Eldoret Municipality, Kenya. Journal of Education and Practice, $6(35)$.

Hackathorn, J., Solomon, E., Blankmeyer, K., Tennial, R. \& Garczynski, A. (2011). Learning by Doing: An Empirical Study of Active Teaching Techniques. The Journal of Effective Teaching. The Journal of Effective Teaching, 11(2), 40-54.

Latief, M. A. (2011). Research Methods On Language Teaching An Introduction. Malang University Press.

Lie, A. (2007). Education policy and EFL curriculum in Indonesia: Between the commitment to competence and quest for higher test scores. TEFLIN Journal, 18(1), 1-14.

Miller, N. (n.d.). Fundamentals of Public Speaking (Version 5.). College of the Canyons.

Morgan, N. (2008). How to become an authentic speaker. Harvard Business Review, 11(86), $115-119$.

Pratama, M. A. (n.d.). FACTORS AFFECTING STUDENTS' CONFIDENCE IN PUBLIC 
SEPAKING. Journal of Languages and Language Teaching, Vol. 5, No. 2.

Nadiah, A. (n.d.). The Students' Self-Confidence in Public Speaking. ELITE Journal, 1(01), 111.

Nation, P., \& Yamamoto, A. (2014). Applying the four strands to language learning. Moving TESOL beyond the Comfort Zone: Exploring Criticality in TESOL, Volume 1, 111-126.

Nowak, A. (2004). Power Speaking, The Art of the Exceptional Public Speaker. Allworth Press.

Oradee, T. (2012). Developing Speaking Skills Using Three Communicative Activities (Discussion, Problem-Solving, and Role Playing). International Journal of Social Science and Humanity, 2(6).

Qutbi, A. (2013). Improving English Oral Communication Skills of Pakistani Public School's Students. International Journal of English Language Teaching, 1(2), 17-36.

Rahman, M. M. (2010). Teaching Oral Communication Skills: A Task-based Approach. ESP World, $9(1(27))$.

Reiser, R. A., \& Dick, W. (1996). Instructional Planning: A Guide for Teacher (2 nd ed). Allyn and Bacon.

Salim, A. (2015). General Self-Confidence and Its Implication on Students' Achievements in Oral Presentation. JEELS, 36.

Solcova, P. (2011). Teaching Speaking Skills. Faculty of Arts of Masaryk University.

Thornbury, S. (2005). How To Teach Speaking. Longman. 